\title{
Validation of Traditional Methods of Genotoxicity with Liver Tyrosine Aminotransferase Activity Induced by Metribuzin Treatment in Albino Rats
}

\author{
Mahmoud M Elalfy ${ }^{\star}$, Mohamed S Aboumosalam and Fathy R Ali Sleem
}

Forensic and Toxicology Department, Mansoura University, Egypt

"Corresponding author: Mahmoud M Elalfy, Faculty of Veterinary Medicine, Forensic and Toxicology Department, Mansoura University, Egypt, Tel: +201007178306; Email: mahmoudelalfy@mans.edu.eg

Rec date: November 05, 2017; Acc date: January 04, 2018; Pub date: January 05, 2018

Copyright: ( 2018 Elalfy MM, et al. This is an open-access article distributed under the terms of the Creative Commons Attribution License, which permits unrestricted use, distribution, and reproduction in any medium, provided the original author and source are credited.

\begin{abstract}
The genotoxicity of pesticides give a potential role in population health and ecosystem safety and here the we would like to explore genotoxicity of metribuzin herbicide. Metribuzin dosed orally in albino rats twice per week for 3 months at dose level $0,110,220$, and $440 \mathrm{mg} / \mathrm{kg}$. All rats were sacrificed and liver was preserved in liquid nitrogen and bone marrow cells was obtained from femur bone. It was founded that chromosomal aberrations were dose dependent with significant increase in all doses (1/20, $1 / 10$ and $1 / 5$ of the LD50\% of metribuzin herbicide) specially higher doses represented by structural abnormalities as chromosomal break, fragments, gap, association and a centromeric chromosomes beside numerical abnormalities as polyploidy and hypoploidy. Additionally, DNA quantity was dose dependent significant increase. Notably, there was significant increase in micronuclei level in respect to control that considered as a clastogenic signal and defect in mitotic activity that founded to be decreased in bone marrow cell where the mitotic index had decreased drastically in comparison to control value. Notably, metribuzin enhanced expression of TAT gene at all doses when compared with control group. on conclusion, metribuzin herbicide had a genotoxic properties that constitute hazard and great concern to population and TAT gene expression could be a potential role in detection of toxicity.
\end{abstract}

Keywords: Metribuzin; Chromosomal aberration detection; Micronuclei and DNA concentration; TAT gene albino rats

\section{Introduction}

To enhance the agricultural production, too large amounts of Pesticides emitted into the environment and showing their effect through genotoxic effect or carcinogenesis, there are three cytogenetic end points micronuclei, sister chromatid exchange and chromosomal aberrations and micronucleus test considered most suitable one [1]. Genotoxic compounds considered as those causing direct or indirect DNA damage. Pesticides as one of those compounds considered as potential mutagenic chemicals with mutagenic properties as chromosomal alteration and DNA damage. The genotoxic effect depends on quantity and formulation of chemical used and tested at both in vivo and in vitro systems [2].

Pesticides testing for carcinogenicity and genotoxicity carried out before market authorization and some prove positive results as micronuclei, chromosomal aberration and sister chromatid exchange that considered as indicator of genotoxicity and increase cancer risk [3].

Metribuzin or 4-amino-6-\{1,1-dimethylethyl\}-3-\{methylthio\}1,2,4-triazin-5 $(4 \mathrm{H})$-one is considered as a potent pre- and postemergent herbicide used to remove a wide range of grass weeds from soybean, potato, sugar cane, tomato and other crops with high water solubility $1.22 \mathrm{mg} / \mathrm{L}$ and has low to moderate persistence in the soil [4]. Also Kimberley et al. and James Morgan reported that LD50\% of metribuzin in rats was $2200 \mathrm{mg} / \mathrm{kg}$ of body weight $[5,6]$.
Metribuzin showed show significant increase in the pituitary and bile duct adenoma at dose level $14.4 \mathrm{mg}$ in a chronic study for 2 years, and classified as class D carcinogen by EPA [7].

Metribuzin showed that significant increase in DNA damage after exposure to metribuzin also moderate genotoxic effect detected in modified SOS microplate assay further increase in DNA adduct observed in in vitro $32 \mathrm{P}$-post labeling study in wing spot test in wing of Drosophila melanogaster [8].

Notably, Alteration of intracellular levels of hydroperoxides and carbonyl proteins and in the activities of catalase, SOD and reduced Glutathione were reported after metribuzin exposure to human and rat spleen lymphocytes reflecting DNA damage and oxidative stress especially at high concentrations [9]. Moreover, the Vanillin had a protective effect of against metribuzin pesticide-induced toxicity and oxidative stress in rats [10].

After exposure to metribuzin in human lymphocytes directly for 24 hours not induce sister chromatid exchange only show cytotoxicity represented as cell death, However pre exposure of metribuzin to Vicia faba roots only for $4 \mathrm{hr}$ (in vivo activation) followed by exposure to human lymphocyte show significant increase in SCE that are concentration dependent and indicator of genotoxicity [11].

In a micronucleus assay in vitro in rat and human spleen lymphocyte Medjdoub et al. declared that metribuzin causes DNA damage and significant increase in micronuclei $(\mathrm{MN})$ frequency in both rat and human lymphocytes at high concentration (50 and 100 $\mu \mathrm{M})$ [9]. 
Metribuzin is positive for the DNA adduct (adduct type 1 with increase 3 to 4 folds while adduct type 2 increase by 5 folds) formation in vitro by using $32 \mathrm{P}$-postlabeling method according to Shah et al. [12].

There was potential correlation between metribuzin exposure and certain malignancies as lymphohematopoietic malignancies suggesting that metribuzin may act as epigenetic carcinogen but additional investigation still required [13]. Metribuzin showed significant increase in DNA damage that aren't dose dependent $(13,53$ and $214 \mathrm{mg} / \mathrm{l})$ out on erythrocytes of Rana catesbeiana tadpoles after application of comet assay [14].

Notably, borlak and elalfy found that diethylnitrosamine as a genotoxic significant increase of liver tyrosine aminotransferase activity [15] and also Dundjerski et al. reported that higher doses of Cadmium decreased both the hepatic glucocorticoid receptor binding of the hormone and to DNA, however, stimulated rat liver tyrosine aminotransferase activity (TAT) [16].

The aim of such study was to validate of traditional methods of genotoxicity with TAT gene expression induced by metribuzin treatment in albino rats.

\section{Materials and Methods}

\section{Experimental animals and grouping}

Male albino rats obtained from experimental unit, Faculty of pharmacy, Mansoura university; weighted from 95 to $115 \mathrm{gm}$. Animals were apparently healthy and housed in plastic cages contain wood shaving as a bedding material. Animals accommodated for 2 weeks before the experiment and maintained on a balanced ration also feed and water given ad libitum throughout the experiment. Rats divided into four groups each one contains eight rats weighed $115 \pm 5$ gm; First group gavaged with distilled water as control while the other three groups intubated with metribuzin orally dissolved in distilled water at dose 110, 220, and $440 \mathrm{mg} / \mathrm{kg}$ of Metribuzin (equivalent to $1 / 20,1 / 10$ and $1 / 5$ of the LD50 of metribuzin (Kimberley et al. and James Morgan) orally twice per week for 3 months. Animals weighed twice per week before dosing to maintain constant dose throughout the experimental period $[5,6]$.

Chromosomal aberration detection: Chromosomal aberration detection technique carried out according to Al-Joubori et al. rats intraperitoneally injected with colchicine $(0.5 \mathrm{mg} / \mathrm{kg}$ body weight $) 3$ hours before sacrificing [17]. The femur removed immediately and bone marrow received in centrifuge tube by injection of $5 \mathrm{ml} \mathrm{KCl}$ $(0.57 \%)$ hypotonic solution then incubated for 20 minutes at $37^{\circ} \mathrm{C}$ followed by centrifugation for 2 minutes at $2000 \mathrm{rpm}$ and supernatant discarded and $5 \mathrm{ml}$ of cold fixative solution (methanol and glacial acetic acid with ratio 3:1) added to precipitate and left at room temperature for 5 minutes followed by centrifugation for 2 minutes at $2000 \mathrm{rpm}$ and such technique repeated twice, then from the $75 \mathrm{~cm}$ by using Pasteur pipette suspension dropped on a clean, moisten and cold slide followed by air drying and staining with giemsa stain solution 5\% and at least investigation of 1000 metaphase cells per each group examined for chromosomal aberration.

DNA preparation, extraction and determination: DNA contents determined by the diphenylamine Procedure colorimetrically according to Karp [18], where after the animals sacrificed the liver removed, washed with saline solution and weighing $1 \mathrm{gm}$ of liver tissue then homogenized with $4 \mathrm{ml}$ cold distilled water, then $2 \mathrm{ml}$ of liver homogenate suspended in $5 \mathrm{ml}$ of $10 \%$ solution of trichloroacetic acid then centrifugation at $3000 \mathrm{rpm}$ for 2 minutes followed by discarding the supernatant and repeating the same technique, Followed by resuspending the pellet in $10 \mathrm{ml}$ ethyl alcohol $95 \%$ followed by centrifugation at $3000 \mathrm{rpm}$ and discarding the supernatant to obtain the purified pellet and such technique repeated with the same way, after that purified pellet resuspended again in $5 \mathrm{ml}$ of trichloroacetic acid TCA $5 \%$ and put in boiling water bath at $90^{\circ} \mathrm{C}$ for 15 minutes then centrifuged and $2 \mathrm{ml}$ of supernatant put in centrifuge tube with $4 \mathrm{ml}$ of diphenylamine reagent $(1 \mathrm{~g}$ of diphenylamine $+100 \mathrm{ml}$ of the glacial acetic acid $+2.5 \mathrm{ml}$ conc. sulphuric acid) followed by putting the centrifuge tubes in boiling water bath for 10 minutes then cooled quickly and observe the change in color, Finally solution then transferred to cuvette for absorbance reading at $600 \mathrm{~nm}$ wavelength and takes the results.

Mitotic index detection: Mitotic index detected according to Sehgal et al. [19] where approximately 3000 cells for each group analyzed for the mitotic index (MI), calculated as the number of divided cells at metaphase per total number cells according to following formula:-

MI\%=Number of the divided cells $\times 100 /$ Total number of the calculated cells.

Micronuclei detection: Micronuclei assay detected according to Gebel et al. [20] where the bone marrow cells from the femur flushed by $5 \mathrm{ml}$ saline solution by using syringe in a centrifuge tube and centrifuged at $4^{\circ} \mathrm{C}$ for $15 \mathrm{~min}$, supernatant discarded, and the pellet was resuspended in $100 \mu \mathrm{l}$ then one drop applied to a glass slide followed by air drying then fixed in methanol solution $95 \%$ for 2 minutes and stained with giemsa stain $5 \%$ stock solution, for counting, at least 1000 examined for each group and number of micronuclei detected from the total number of cells. The chi-square test used to determine the significance and the total chi-square.

\section{RNA isolation, reverse transcription and RT-PCR}

The trizol reagent kit was used for total RNA extraction from liver tissue. Reverse transcription was carried out using Superscript II reverse transcriptase. Primers that were used: Primer sequences for TAT were 5-TGGAGTTCACAGAGCGGTTG-3 (forward) and 5GGTACTCGAAGCACGTTGCTG-3 (reverse) and b-actin 5ggcattgttaccaactgggacg-3, 3- ctctttgatgtcacgcacgatttc-5 [21]. Moreover, Conditions for RT-PCR were as follows: $10 \mathrm{~min}$ at $95^{\circ} \mathrm{C}$ followed by $40-50$ cycles of $15 \mathrm{~s}$ at $95^{\circ} \mathrm{C}, 15 \mathrm{~s}$ at $60^{\circ} \mathrm{C}$, and $15 \mathrm{~s}$ at $72^{\circ} \mathrm{C}$. RT-PCR was performed as previously described.

\section{Statistical Analysis}

The results were statistically evaluated using Student's " $\mathrm{t}$ " test. (Trial SPSS 2013). There was no fund shared in this article and all requirement paid by authors. There was no conflict of interest for all authors.

\section{Results}

Detection of chromosomal aberration in rats bone marrow exposed 110,220 , and $440 \mathrm{mg} / \mathrm{kg}$ (equivalent to $1 / 20,1 / 10$ and $1 / 5$ of the LD50 of metribuzin) of Metribuzin given orally twice per week for 3 months.

Chromosomal aberration were dose dependent with significant increase in all doses $(1 / 20,1 / 10$ and $1 / 5$ of the LD50) specially higher doses represented by structural abnormalities as chromosomal break, 
Citation: Elalfy MM, Aboumosalam MS, Sleem FRA (2018) Validation of Traditional Methods of Genotoxicity with Liver Tyrosine Aminotransferase Activity Induced by Metribuzin Treatment in Albino Rats. J Vet Sci Technol 9: 500. doi:10.4172/2157-7579.1000500

Page 3 of 6

fragments, gap, association and a centromeric chromosomes beside numerical abnormalities as polyploidy and hypoploidy where the results illustrated in Figure 1 and Table 1.

\begin{tabular}{|l|l|l|l|l|l|l|l|l|l|}
\hline Group & Total & Break & Fragment & Gap & Ring & $\begin{array}{l}\text { Chromosomal } \\
\text { association }\end{array}$ & $\begin{array}{l}\text { Acentromeric } \\
\text { chromosome }\end{array}$ & Hypoploidy & Polyploidy \\
\hline G 1 & $2 \pm 0.26^{\mathrm{d}}$ & $0.5 \pm 0.18^{\mathrm{d}}$ & $0.63 \pm 0.26^{\mathrm{d}}$ & $0.75 \pm 0.16^{\mathrm{d}}$ & $0^{\mathrm{d}}$ & $0^{\mathrm{d}}$ & $0^{\mathrm{c}}$ & $0^{\mathrm{c}}$ & $0^{\mathrm{d}}$ \\
\hline $\begin{array}{l}\text { G 2 (1/20 of LD } \\
50 \%)\end{array}$ & $11.87 \pm 0.51^{\mathrm{c}}$ & $2.37 \pm 0.18^{\mathrm{c}}$ & $2.13 \pm 0.13^{\mathrm{c}}$ & $2.63 \pm 0.26^{\mathrm{c}}$ & $1.75 \pm 0.16^{\mathrm{c}}$ & $0.75 \pm 0.16^{\mathrm{c}}$ & $0.88 \pm 0.22^{\mathrm{b}}$ & $0.75 \pm 0.16^{\mathrm{b}}$ & $0.75 \pm 0.16^{\mathrm{c}}$ \\
\hline $\begin{array}{l}\text { G 3 (1/10 of LD } \\
50 \%)\end{array}$ & $25.62 \pm 0.23^{\mathrm{b}}$ & $4 \pm 0.18^{\mathrm{b}}$ & $4.25 \pm 0.35^{\mathrm{b}}$ & $4.13 \pm 0.22^{\mathrm{b}}$ & $3.38 \pm 0.32^{\mathrm{b}}$ & $2.13 \pm 0.22^{\mathrm{a}}$ & $2 \pm 0.26^{\mathrm{a}}$ & $2.75 \pm 0.36^{\mathrm{a}}$ & $3 \pm 0.26^{\mathrm{b}}$ \\
\hline $\begin{array}{l}\text { G 4 (1/5 of LD } \\
50 \%)\end{array}$ & $37.75 \pm 0.88^{\mathrm{a}}$ & $7 \pm 0.26^{\mathrm{a}}$ & $7 \pm 0.42^{\mathrm{a}}$ & $6.63 \pm 0.32^{\mathrm{a}}$ & $6.5 \pm 0.26^{\mathrm{a}}$ & $1.63 \pm 0.18^{\mathrm{b}}$ & $1.75 \pm 0.25^{\mathrm{a}}$ & $2.25 \pm 0.31^{\mathrm{a}}$ & $5 \pm 0.26^{\mathrm{a}}$ \\
\hline
\end{tabular}

Table 1: Detection of chromosomal aberration in rats' bone marrow exposed to 110, 220, and $440 \mathrm{mg} / \mathrm{kg}$ of A, b, c, d: Different letters are significantly different between groups $(\mathrm{p}<0.05)$.

a

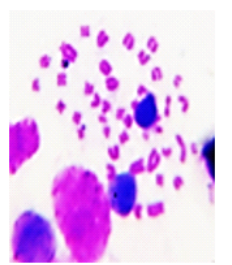

d

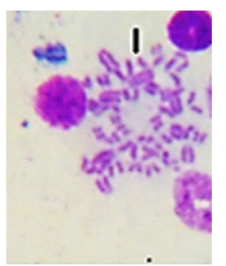

g

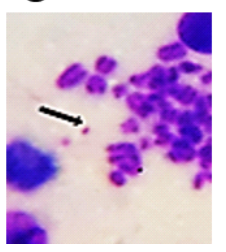

b

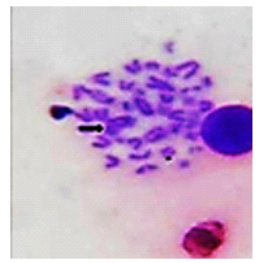

e

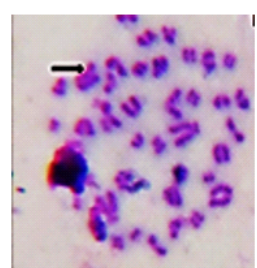

$\mathrm{h}$

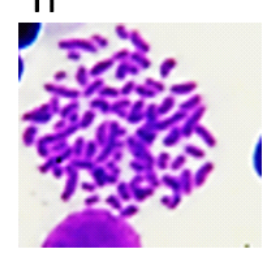

C

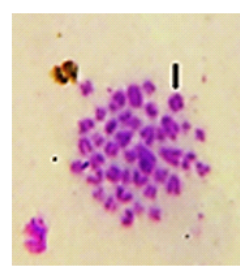

$f$

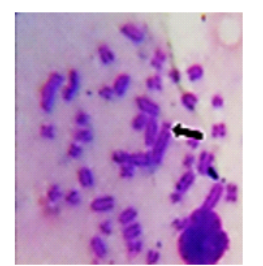

i

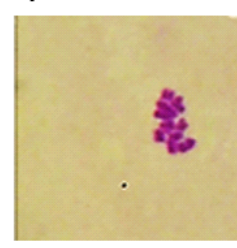

Figure 1: Bone marrow cell of rats in metaphase spread showing a) normal chromosome in metaphase b) chromosomal association c) Ring d) hypoploidy e) A centromeric Chromosome f) gap g) break h) fragment i) polyploidy at dose level 1/ 5 of LD50 of metribuzin administered orally for 3 months twice per week.

Estimation of DNA in liver tissue of rats administered metribuzin at dose level 110, 220, and $440 \mathrm{mg} / \mathrm{kg}$ of Metribuzin (equivalent to $1 / 20$, $1 / 10$ and $1 / 5$ of the LD50 of metribuzin) given orally twice per week for 3 months.

Two doses of metribuzin ( $1 / 5$ and $1 / 10$ of LD50) showed significance increase in quantity of DNA after 3 months of administration compared to control group as illustrated in Table 2.

\begin{tabular}{|c|c|c|c|c|}
\hline & Control & Group 2 & Group 3 & Group 4 \\
\hline $\begin{array}{l}\text { DNA concentration } \\
(\mathrm{mg} / \mathrm{kg})\end{array}$ & $13.4 \pm 0.4$ & $15.8 \pm 0.8$ & $\begin{array}{ll}18.8 & \pm \\
0.12 a & \end{array}$ & $\begin{array}{l}20.6 \\
0.17 a\end{array}$ \\
\hline
\end{tabular}

Table 2: Showing Estimation of DNA in liver tissue of rats administered Metribuzin at dose level 110, 220, and $440 \mathrm{mg} / \mathrm{kg}$ (equivalent to $1 / 20,1 / 10$ and $1 / 5$ of the LD50 of metribuzin) of Metribuzin given orally twice per week for 3 months.

Mitotic index detection in rats' bone marrow exposed to 110,220 , and $440 \mathrm{mg} / \mathrm{kg}$ (equivalent to $1 / 20,1 / 10$ and $1 / 5$ of the LD50 of metribuzin) of Metribuzin given orally twice per week for 3 months.

The result according to chi square analysis showed that significant difference in mitotic index between treated and control groups where there is a dose dependent significant decrease in mitotic index in rats exposed to $(1 / 20,1 / 10$ and $1 / 5$ of the LD50) of Metribuzin equivalent to $(440,220$ and $110 \mathrm{mg} / \mathrm{kg})$ in comparison with the control group (Tables 3 and 4).

\begin{tabular}{|l|l|l|l|l|}
\hline Group & $\begin{array}{l}\text { Total no. } \\
\text { of } \\
\text { counted } \\
\text { cells }\end{array}$ & $\begin{array}{l}\text { No. of } \\
\text { divided cells }\end{array}$ & $\begin{array}{l}\text { No. of non-divided } \\
\text { cells }\end{array}$ & M.I \\
\hline G 1 & 3000 & 123 & 2877 & 4.1 \\
\hline $\begin{array}{l}\text { G 2 (1/20 of LD } \\
50 \%)\end{array}$ & 3000 & 92 & 2908 & 3.06 \\
\hline $\begin{array}{l}\text { G 3 (1/10 of LD } \\
50 \%)\end{array}$ & 3000 & 81 & 2919 & 2.7 \\
\hline $\begin{array}{l}\text { G 4 (1/5 of LD } \\
50 \%)\end{array}$ & 3000 & 75 & 2925 & 2.5 \\
\hline Total chi-square=15.23* & $\begin{array}{l}\text { Degree of } \\
\text { freedom=3 }\end{array}$ & Probability=0.0016 & \\
\hline
\end{tabular}

Table 3: Show Mitotic index detection in rats' bone marrow exposed to 110,220 , and $440 \mathrm{mg} / \mathrm{kg}$ of Metribuzin (equivalent to $1 / 20,1 / 10$ and $1 / 5$ of the LD50 of metribuzin) given orally twice per week for 3 months. 
Citation: Elalfy MM, Aboumosalam MS, Sleem FRA (2018) Validation of Traditional Methods of Genotoxicity with Liver Tyrosine Aminotransferase Activity Induced by Metribuzin Treatment in Albino Rats. J Vet Sci Technol 9: 500. doi:10.4172/2157-7579.1000500

Page 4 of 6

\begin{tabular}{|l|l|l|l|l|}
\hline & Control & G 1/20 & G 1/10 & G 1/5 \\
\hline G1 & & & & \\
\hline $\begin{array}{l}\text { G 2 (1/20 of } \\
\text { LD 50\%) }\end{array}$ & $4.43^{*}$ & & & \\
\hline $\begin{array}{l}\text { G 3 (1/10 of } \\
\text { LD 50\%) }\end{array}$ & $8.53^{*}$ & 0.6 & & \\
\hline $\begin{array}{l}\text { G 4 (1/5 of LD } \\
50 \%)\end{array}$ & $11.54^{*}$ & 1.58 & 0.16 & \\
\hline
\end{tabular}

twice per week for 3 months. ${ }^{*}$ value means that there was significant difference between the control and the treated groups at the dose level of $(\mathrm{p}<0.05)$. ** Value means that there was a highly significant difference between the control and the treated groups at the dose level of $(\mathrm{p}<0.001)$.

Table 4: Show chi square analysis of Mitotic index of groups treated with 110,220 , and $440 \mathrm{mg} / \mathrm{kg}$ of Metribuzin. *value means that there was significant difference between the control and the treated groups at the dose level of $(\mathrm{p}<0.05)$. ${ }^{* *}$ Value means that there was a highly significant difference between the control and the treated groups at the dose level of $(\mathrm{p}<0.001)$.

Micronuclei assay detection in rats' bone marrow exposed to 110 , 220 , and $440 \mathrm{mg} / \mathrm{kg}$ (equivalent to $1 / 20,1 / 10$ and $1 / 5$ of the LD50 of metribuzin) of Metribuzin given orally twice per week for 3 months.

The result according to chi square analysis showed that a highly significant change between the control and treated groups where there is a dose dependent highly significant increase in micronuclei in rats exposed to $(1 / 20,1 / 10$ and $1 / 5$ of the LD50) of Metribuzin in comparison with the control group (Figure 2, Tables 5 and 6).

\begin{tabular}{|l|l|l|l|}
\hline Group & $\begin{array}{l}\text { Total no. of } \\
\text { examined } \\
\text { cells }\end{array}$ & $\begin{array}{l}\text { No. } \\
\text { micronuclei }\end{array}$ & No. of normal cells \\
\hline G1 & 2000 & 187 & 1813 \\
\hline $\begin{array}{l}\text { G 2 (1/20 of LD } \\
50 \%)\end{array}$ & 2000 & 285 & 1715 \\
\hline $\begin{array}{l}\text { G 3 (1/10 of LD } \\
50 \%)\end{array}$ & 2000 & 322 & 1678 \\
\hline G 4 (1/5 of LD 50\%) & 2000 & 392 & 1609 \\
\hline $\begin{array}{l}\text { Total chi- } \\
\text { square=86.57* }\end{array}$ & & $\begin{array}{l}\text { Degree } \\
\text { freedom=3 }\end{array}$ & Probability=000 \\
\hline
\end{tabular}

Table 5: Show Micronuclei assay detection in rats' bone marrow exposed to 110,220 , and $440 \mathrm{mg} / \mathrm{kg}$ (equivalent to $1 / 20,1 / 10$ and $1 / 5$ of the LD50 of metribuzin) of Metribuzin given orally twice per week for 3 months.

\begin{tabular}{|l|l|l|l|l|}
\hline & Control & G 1/20 & G 1/10 & G 1/5 \\
\hline Control & & & & \\
\hline $\begin{array}{l}\text { G 2 (1/20 of LD } \\
50 \%)\end{array}$ & $22.60^{\star *}$ & & & \\
\hline $\begin{array}{l}\text { G 3 (1/10 of LD } \\
50 \%)\end{array}$ & $40.42^{\star *}$ & 2.51 & & \\
\hline $\begin{array}{l}\text { G 4 (1/5 of LD } \\
50 \%)\end{array}$ & $83.92^{\star *}$ & $19.91^{\star *}$ & $8.07^{\star}$ & \\
\hline
\end{tabular}

Table 6: Show chi square analysis of Micronuclei assay detection in rats' bone marrow exposed to 110,220 , and $440 \mathrm{mg} / \mathrm{kg}$ (equivalent to $1 / 20$, $1 / 10$ and $1 / 5$ of the LD50 of metribuzin) of Metribuzin given orally

Figure 2: Showed micronuclei in rats bone marrow cells exposed to metribuzin at dose level 110,220 , and $440 \mathrm{mg} / \mathrm{kg}$ of metribuzin (equivalent to $1 / 20,1 / 10$ and $1 / 5$ of the LD50 of metribuzin) given orally twice per week for 3 months.

\section{TAT gene expression by Rt-PCR}

It was found that TAT gene expression could correlate with genotoxicity of metribuzin when compared with control group (Figure 3).

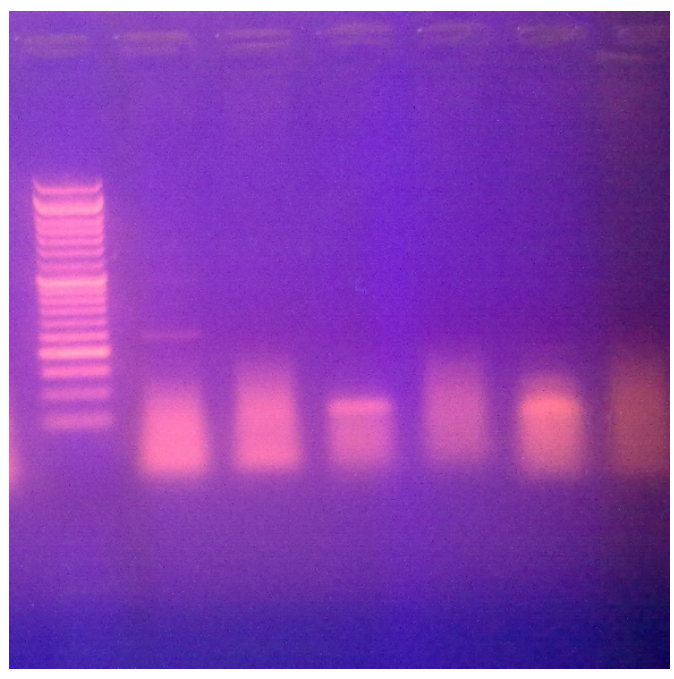

Figure 3: Show gel detection Rt-PCR of TAT gene expression in all doses of metribuzin compared with control in last lan.

Volume 9 Issue 1.1000500 


\section{Discussion}

Chromosomal aberration were increased significantly in all doses specially at higher dose represented by both structural abnormalities and numerical abnormalities such results agree with Kaya et al. [8] who proposed that in a study in the wing of Drosophila melanogaster somatic mutation and recombination or wing spot test by using of four different concentration of the herbicide and results show that significant increase in DNA damage after exposure to metribuzin also moderate genotoxic effect detected in modified SOS microplate assay further increase in DNA adduct observed in in vitro 32 P-post labeling study. Also agree with Delancey et al. who reported that in a survey study to detect the correlation between the incidence of cancer and the exposure to metribuzin and potential correlation between metribuzin exposure and certain malignancies as lymphohematopoietic malignancies suggesting that metribuzin may act as epigenetic carcinogen [13]. Moreover, Clements et al. [14] declared that in Single cell gel electrophoresis or comet assay carried out on erythrocytes of Rana catesbeiana tadpoles to detect damage in DNA after exposure to metribuzin and other four herbicides, metribuzin showed significant increase in DNA damage that were not dose dependent. Notably, Shah et al. founded also that metribuzin was positive for the DNA adduct detected in in-vitro study by using 32P-postlabeling method [12].

Metribuzin at dose of $1 / 5$ and $1 / 10$ of LD50 resulted in significant increase in quantity of DNA after 3 months of administration compared to control group and such results inconsistent with Shah et al. where metribuzin was positive for the DNA adduct presence in vitro studies by using 32P-postlabeling method [12]. Also metribuzin considered as a pre-carcinogenic reported that in a study of rats at dose level $0,1.3,1.9,5.3$ and $14.4 \mathrm{mg}$ metribuzin $/ \mathrm{kg} /$ day in male rats showed significant increase in the pituitary and bile duct adenoma [7]. Additional, Gowri et al. found primary lesions as breaks, DNA protein crosslink and eventually loss of cell structure also proliferation with a total control loss of cellular mechanism may occur leads to increase quantity of DNA synthesis and mutagenicity [22]. On the other hand disagree with Soliman and Ghoneam, they founded that DNA content decreased than control and decrease the DNA synthesis and replication in Vicia faba after exposure to metribuzin [23].

Mitotic index was significant difference between treated and control groups in a dose dependent significant decrease in mitotic index in rats exposed to $(1 / 20,1 / 10$ and $1 / 5$ of the LD50) of metribuzin equivalent to $(110,220$ and $440 \mathrm{mg} / \mathrm{kg})$ in comparison with the control group and such results come in agreement with Haliem, [24] who reported that metribuzin cause a drastic decrease in mitotic index of Allium cepa meristematic cells and also according to Baszynski et al. attributed to inhibition of protein synthesis especially certain nuclear proteins that was essential in mitotic cycle so decrease the mitotic activity [25].

Micronuclei were increased in a dose dependent manner in rats exposed to $(1 / 20,1 / 10$ and $1 / 5$ of the LD50) of Metribuzin equivalent to $(440,220$ and $110 \mathrm{mg} / \mathrm{kg})$ in comparison with the control group and such results inconsistent with Medjdoub et al. who proposed that in a micronucleus assay in vitro in rat and human spleen lymphocyte metribuzin causes DNA damage and significant increase in micronuclei frequency in both rat and human lymphocytes at high concentration [9]. The micronuclei test considered as a potential test to assess genotoxicity also according to Maya et al. who reported that pre exposure of metribuzin to Vicia faba roots only for $4 \mathrm{hr}$ (in vivo activation) followed by exposure to human lymphocyte show significant increase in SCE and micronuclei that were concentration dependent and indicator of genotoxicity.
Metribuzin enhanced expression of TAT gene at all doses of treatment and these results agree with unpublished data of Borlak and Elalfy [15] and Dundjerski et al. [16] who found correlation of expression of Dundjerski et al. with toxins like diethylnitrosamine or cadmium.

On conclusion, metribuzin herbicide had a genotoxic properties that constitute detected by traditional methods or expression of TAT gene as a new tools for genotoxicity.

This research received no specific grant from any funding agency in the public, commercial, or not-for-profit sectors.

\section{Conflict of Interest}

Authors have no conflict of interest.

\section{References}

1. Tolga C (2011) In vivo genotoxicity evaluation of atrazine and atrazinebased herbicide on fish Carassius auratus using the micronucleus test and the comet assay. Food Chem Toxicol 49: 1431-1435.

2. Claudia B, Gabriella M (2000) Genotoxicity of pesticides: potential risk for consumers. Trends Food Sci Technol 11: 182-187.

3. Bull S, Fletcher K, Boobis AR, Battershill JM (2006) Evidence for genotoxicity of pesticides in pesticide applicators: a review. Mutagenesis 21: 93-103.

4. Shive CMS, Pratibha K (2007) Biomimetic oxidation of metribuzin with hydrogen peroxide catalyzed by $5,10,15,20$-tetraaryl porphyrinato iron (III) chlorides. Tetrahedron Letters 48: 5035-5038.

5. Kimberley G, Solecke B, Lorke D (1969) Toxicological studies from Dr. George Kimmerle and Dr. Brigitte Solecki: Report No. 1574; 25942.

6. James Morgan (2001) Evidence on the developmental and reproductive toxicity of metribuzin. California Environmental Protection Agency.

7. Loser E, Mohr U (1974) Bay 94337: Chronic toxicity studies on rats (Two-year feeding experiment on metribuzin): Report No. 4888; Report No. 41816. Unpublished study. Submitted by Mobay Chemical Corp, Kansas City, MO. (MRID 00061261).

8. Bulent K, Attila Y, Amadeo C, Ricardo M (2000) Genotoxicity testing of five herbicides in the Drosophila wing spot test. Mutat Res 46: 577-584.

9. Medjdoub A, Merzouk SA, Merzouk H, Chiali FZ, Narce M (2011) Effects of Mancozeb and Metribuzin on in vitro proliferative responses and oxidative stress of human and rat spleen lymphocytes stimulated by mitogens. Pesticide Biochemistry Physiology 101: 27-33.

10. Lilia K, Ezzeddine B, Mongi S, Amel B, Assia D, et al. (2016) Ameliorative Effects of Vanillin Against Metribuzin-Induced Oxidative Stress and Toxicity in Rats. Int J Pharm Pharm Sci 9: 56-62.

11. Flores MS, Sandra GA, Calderon SME, Villalobos PR, Stefan MW, et al. (2005) Promutagen activation of triazine herbicides metribuzin and ametryn through Vicia faba metabolism inducing sister chromatid exchanges in human lymphocytes in vitro and in $V$. faba root tip meristems. Toxicol In Vitro 19: 243-251.

12. Shah RG, Lagueux J, Kapur S, Levallois P, Ayotte P, et al. (1997) Determination of genotoxicity of the metabolites of the pesticides Guthion, Sencor, Lorox, Reglone, Daconil, and Admire by 32Ppostlabeling. Mol Cell Biochem 169: 177-184.

13. Oliver DJL, Michael ACR, Joseph C, Aaron B, Jane HA, et al. (2009) Occupational Exposure to Metribuzin and the Incidence of Cancer in the Agricultural Health Study. Ann Epidemiol 19: 388-395.

14. Chris C, Steven R, Michael P (1997) Genotoxicity of Select Herbicides in Rana catesbeiana Tadpoles Using the Alkaline Single Cell Gel DNA Electrophoresis (Comet) Assay. Environ Mol Mutagen 29: 277-288.

15. Borlak J, Elalfy M (2017) Computation analysis of Differentially Expressed and Alternately Spliced 2 Genes Identify genotoxic and non- 
Citation: Elalfy MM, Aboumosalam MS, Sleem FRA (2018) Validation of Traditional Methods of Genotoxicity with Liver Tyrosine Aminotransferase Activity Induced by Metribuzin Treatment in Albino Rats. J Vet Sci Technol 9: 500. doi:10.4172/2157-7579.1000500

Page 6 of 6

genotoxic in c-myc transgenic mouse 3 model. unpublished experimental finding.

16. Dundjerski J, Butorović B, Kipić J, Trajković D, Matić G (1996) Cadmium affects the activity of rat liver tyrosine aminotransferase and its induction by dexamethasone. Arch Toxicol 70: 390-395.

17. Maysaa AA, Haider ZK, Saadi A, Ali H (2014) Evaluation of Chromosome Aberrations and Mitotic Index in Alloxan-Induced Diabetic Male Rats Treated with the Mixture of Plants Extracts Mixture. J Babylon Univ/Pure and Appl Sci 22: 1-11.

18. Gerald K (2013) Cell and Molecular Biology New York: John Wiley \& Sons, Inc.

19. Sehgal R, Roy S, Kumar DV (2006) Evaluation of cytotoxicity potential of latex of Calotropis procera and podophyllotoxin in Allium cepa root model. Biocell 30: 9-13.

20. Thomas G, Sebastian K, Katharina P, Rudolf E, Hartmut D (1997) In vivo genotoxicity of selected herbicides in the mouse bone-marrow micronucleus test. Arch Toxicol 71: 193-197.
21. Tadic SD, Elm MS, Li HS, Van Londen GJ, SUbbotin VM, et al. (2002) Sex differences in hepatic gene expression in a rat model of ethanol-induced liver injury. J Appl Physiol 93: 1057-1068.

22. Gowri B, Govindasamy P, Ramalingam V (2013) Influence of Cypermethrin on DNA and RNA Content in Different Organs of Freshwater Fish Cyprinus carpio. Iran J Pharm Sci 9: 1-10.

23. Magda SI, Ghada GT (2004) The mutagenic potentialities of some herbicides using Vicia faba as a biological system. Biotechnol 3: 140-154.

24. Haliem AS (1990) Cytological effect of the herbicide Sencor on mitosis of Allium cepa. Egypt J Bot 33: 93-104.

25. Baszynski CL, Walden BD, Atkinson GB (1980) Cycloheximide induced nuclear alteration in maize root tips. Can J Genet 22: 319-331. 